\title{
Eleştirel Jeopolitik Çerçevesinde Akıllı Şehirler ve Şehir Jeopolitiği
}

\author{
M.Cem OĞULTÜRK* \\ Güngör ŞAHİN**
}

\begin{abstract}
$\ddot{O} \mathbf{z}$
Çalışmanın konusunu hem ulusal hem de uluslararası seviyede hızla artan şehir nüfusu ve şehirleşme ile ortaya çıkan yeni güvenlik risk ve tehditleri karşısında gelişen yeni yaklaşımlardan "şehir jeopolitiği" kavramı oluşturmaktadır. Bu çalışmanın önemi; güvenliğin genişlemesi olarak adlandırılan günümüzdeki güvenlik konularının çeşitlenmesi, güvenliğin derinleşmesi olarak adlandırılan artık bir bireyin bile küresel etki yaratabileceği aktör sayısının artması ile ortaya çıkabilecek risk ve tehditler karşısındaki yeni yaklaşım ihtiyacından kaynaklanmaktadır. Çalışma, şehir nüfusunun ve şehirlerin kapsadığı alanın artması sonucu; savaş, terör ve şiddet eylemleri gibi insan güvenliği konularının merkezinde yer alan şehirlerdeki yapısal şiddete yol açan problemlerin ortaya çıkarılması ve önlenmesi için "şehir jeopolitiği" yaklaşımını kullanmayı amaçlamaktadır. Bu çalışmanın kuramsal çerçevesini; mevcut kuvvet-zaman-mekân ilişkisi bağlamında gelişen jeopolitik yaklaşım karşısında yeni ortaya çıkan güvenlik sorunlarıyla mücadelede alternatifler ve stratejik yaklaşımlar getiren eleştirel jeopolitik oluşturmaktadır. Çalışmanın bulguları; şehir jeopolitiğinin, şehirde güvenliğinin korunması ve sağlanması ile beraber şehrin her bakımdan yaşanabilir olmasında, ilgili aktörleri ve sorumluluk alanlarını net bir şekilde tanımlamak ve bu aktörler arasında iş birliği bilincini geliştirecek ortak dil yaratmak için araç olarak kullandığını belirtmektedir.
\end{abstract}

Anahtar Kelimeler: Şehir Jeopolitiği, Eleştirel Jeopolitik, Akıllı Şehirler, Güvenlik, Tehdit.

\section{Smart Cities and Urban Geopolitics in the Context of Critical Geopolitics}

\begin{abstract}
The subject of the study is the concept of "urban geopolitics", one of the new approaches that develops in the face of new security risks and threats emerging with the rapidly increasing urban population and urbanization at both national and international levels. The importance of this research study; The diversification of today's security issues, which is called the expansion of security, the deepening of security stems from the need for a new approach to the risks and threats that may arise with the increase in the number of actors that even an individual can create global impact. This study, as a result of the increase in urban population and the area covered by cities; It aims to use the "urban geopolitics" approach to reveal and prevent the problems that lead to structural violence in cities that are at the center of human security issues such as war, terrorism and acts of violence. The theoretical framework of this study; In the face of the geopolitical approach that develops in the context of the current force-time-space relationship, it creates a critical geopolitics that brings alternatives and strategic approaches in the fight against newly emerging security problems. Findings of the research; the city geopolitics is used as a tool in order to clearly define the actors and their areas of responsibility related to the protection and ensuring the security of the city and the livability of the city in all respects and to create a common language that will develop the awareness of cooperation between these actors.
\end{abstract}

Key Words: Urban Geopolitics, Critical Geopolitics, Smart Cities, Security, Threat.

Geliş/Received: 05. 11. 2020

Kabul/Accepted: 21. 12. 2020

* Bu çalışma, insanlardan veri ve örnek toplamayı gerektiren, anket, inceleme, alan çalışması ve deney içeren araştırmalar 'kapsamına girmediğinden etik kurul onay belgesi gerektirmemektedir.

\footnotetext{
* Dr., Millî Savunma Üniversitesi Misafir Öğretim Üyesi, cogulturk@gmail.com, ORCID: 0000-0003-2619-9559.

** Dr. Öğr. Üyesi, Millî Savunma Üniversitesi, Atatürk Stratejik Araştırmalar Enstitüsü (ATASAREN), Strateji ve Güvenlik Araştırmaları Anabilim Dalı Öğretim Üyesi, gsahin@msu.edu.tr, ORCID: 0000-0001-6296-8568.

(Makale türü: Araştırma makalesi)
} 


\section{M.Cem OĞULTÜRK' Güngör ŞAHIN}

Eleştirel Jeopolitik Çerçevesinde Akıllı Şehirler ve Şehir Jeopolitiği

\section{Giriş}

1950'li yıllarda dünya nüfusunun yaklaşı üçte biri şehirlerde yaşarken 2010'da bu oran \%50'yi aşmıştır. 2050'ye gelindiğinde ise \%70'ler seviyesinde yaklaşık 5 milyar insanın şehirlerde yaşayacağı öngörülmektedir. Türkiye'de de dünyadaki gelişmelere benzer olarak, 2017 verilerine göre şehirleşme oran1 \%88'e ulaşmış ve 2050'de nüfusun \%95'inin şehirlerde yaşayacağ tahmin edilmektedir (Çevre ve Şehircilik Bakanlığ1, 2017). Günümüzde şehirler hızla büyümekte, modernleşmekte ve sosyal, siyasal, ekonomik, hukuksal olağanüstü bir değişim göstermektedir. Modern şehirlerde yaşayan insanlar ulaşım, iletişim, ekonomide yaşanan olağanüstü gelişmeler ve küreselleşmenin etkisiyle; şehir içi, şehirlerarası, bölgesel, ulusal ve hatta uluslararası ölçekte ilişkiler ağı geliştirmişlerdir. Bu ilişkilerin oluşturulmasında güç ve rekabet önemini artırırken, fiber-optik temelli iletişim kanalları hızlandıran bir etki yaratmıştır (Graham, 1998). İnsanoğlunun yaratıcıllğında şehirler, sibernetik sistemlerle güçlenerek zenginleşmekte, gelişmekte ve eşsiz bir hal almaktadır. Bununla birlikte şehirlerde giderek artan ekonomik rekabet, gelir dağılımındaki eşitsizlik, hızlı artan nüfus karşısında istihdamın azalması başta terör örgütleri olmak üzere insanların duygularının manipüle edilmesini kolaylaştırmakta; şehirleri şiddet, etnik ve mezhepsel çatışmalar, gösteri, grev, terör eylemleri için uygun ve güvensiz alanlar haline getirmektedir. Çalışmanın konusunu hem ulusal hem de uluslararası seviyede hızla artan şehir nüfusu ve şehirleşme ile ortaya çıkan yeni güvenlik risk ve tehditleri karşısında gelişen yeni yaklaşımlardan "şehir jeopolitiği” kavramı oluşturmaktadır.

Geçmişten bugüne toplumun en önemli problemlerinden biri olan güvenlik ve bundan kaynaklanan sorunların çözülmesi, güvenliğin yeniden tesis edilmesi, devletin en temel görevlerinden sayılmaktadır. Çünkü güvenlik, doğal ve toplumsal bir ihtiyaçtır. Güvenlik ihtiyacı insanları birlikte yaşamaya iten nedenlerin başında gelmiş ve sonucunda şehirler inşa edilmiştir. Özellikle büyük şehirlerin (metropollerin) yaygınlaşması ve nüfusun büyük bir kısmının şehirlerde yerleşmesi güvenlik konusunda yeni yaklaşımların ele alınmasını gerekli kılmıştır. Tepkisel stratejilerin suçla mücadelede ve güvenliğin tesisinde etkinliğinin sınırlı olması, suça karşı mücadelede önleyici tedbirler alınmasının gerekliliği konusu yapılan araştırmalarda ortaya konmuştur (Küçükay, 2019). Suçla mücadelede eski usul yargılar ve araçların kullanılması ise toplumsal yaşam kalıplarını olumsuz yönde etkilemektedir. Çalışma, şehir nüfusunun ve şehirlerin kapsadığı alanın artması sonucu; savaş, terör ve şiddet eylemleri gibi insan güvenliği konularının merkezinde yer alan şehirlerdeki yapısal şiddete yol açan problemlerin ortaya çıkarılması ve önlenmesi için “şehir jeopolitiği” yaklaşımını kullanmayı amaçlamaktadır.

Çağdaş güvenlik anlayışı, suçludan ziyade suç olgusu ile mücadele etmeyi gerektirmektedir. Bir diğer ifade ile günümüzün güvenlik anlayışı olan suçluyu cezalandırmaya ve meydana gelen olayları bastırmaya dayanan tepkisel/reaktif stratejilerden ziyade, suç henüz oluşmadan suçu önlemeyi hedefleyen proaktif bir bakış açısına dayanmaktadır. Bu bakış açısı, 
suça neden olan faktörleri tespit etmeyi ve bu faktörleri ortadan kaldırmay1 gerektirmektedir. Güvenlik tehditleri süreç içerisinde siyasi, sosyal, ekonomik, kültürel ve demografik yap1 içerisinde oluşmaktadır.

Çok boyutlu güvenlik stratejileri gerektiren proaktif güvenlik anlayış1; eğitim, sosyal hizmetler, yerel ve merkezi yönetimler, sivil toplum, akademi ve iş dünyası gibi pek çok alanı kapsayan bütüncül planlamalardan meydana gelmektedir. Şehirlerin güvenliği sadece terör, toplumsal ve yapısal şiddet, asayiş, uyuşturucu, organize suçlar ve benzerleri tarafindan tehdit edilmemektedir. İnsan ve doğa kaynaklı afetler de şehir güvenliğini tehdit eden temel faktörler arasında yer almaktadır. Bu çalışmanın önemi; güvenliğin genişlemesi olarak adlandırılan günümüzdeki güvenlik konularının çeşitlenmesi, güvenliğin derinleşmesi olarak adlandırılan artık bir bireyin bile küresel etki yaratabileceği aktör sayısının artması ile ortaya çıkabilecek risk ve tehditler karşısındaki yeni yaklaşım ihtiyacından kaynaklanmaktadır.

Hızla kentleşen gezegenimizde, dünyanın artan şehirli nüfusunun günlük yaşamı, coğrafi alana yayılan geniş ve bilinemeyecek kadar karmaşı altyapı ve teknoloji sistemlerine giderek daha fazla bağımlı hale gelmektedir. Enerji ağları ve altyapı aracılı̆̆ıyla kentsel yaşamın enerji ihtiyacı sürekli karşılanmakta, aynı zamanda uzaktaki enerji kaynaklarına bağımlılık artmaktadır. Büyük su sistemleri ile şehrin su ihtiyacı giderilmekte; katı atıklar ve sular, kanalizasyon ve çöplerin toplanması gibi yollarla şehrin içinden (en azından kısmen) uzaklaştırılmaktadır. Küresel tarım, nakliyeciler ve sebze-meyve halleri şehirlerdeki milyonlarca insana yiyecek sağlamaktadır. Karayolu, havayolu, demiryolu kompleksleri; küresel-kentsel sistem ve çevre bölgeler aracılığıyla araçların, iş gücünün, göçmenlerin, turistlerin ve mültecilerin ulaşımlarının yanı sıra malzeme ve mal akışlarını desteklemektedir. Elektronik iletişim sistemleri, dijital kapitalizmin can damarı olarak aracılık edilen bilgi, işlem, etkileşim ve eğlence evrenini sağlamaktadır (Graham, 2010). Bu altyapıların korunması, bu altyapıların zarar görmesinden kaynaklanacak sorunların öngörülmesi ile gerekli tedbirlerin alınması konuları şehir jeopolitiği ve güvenlik çalışmalarının ilgi alanına girmektedir.

Uluslararas1, ulusal, devlet, şirket veya şehir güvenliği siyaseti kapsamında; şehir yaşamını destekleyen altyapıların, her türden devlet veya devlet dışı aktör tarafından saldırıya uğramasının şehir için yaşamsal bir öneme sahip olduğu ileri sürülmektedir (Graham, 2010). Altyapı ve güvenlik arasındaki bağlantılar üzerine etkili bir ABD yorumcusu olan John Robb, düzenli olarak "Küresel altyapı ağları büyük güçlerin Aşil topuğudur. Zenginliğimizin ve günlük işlevimizin temelini oluşturuyorlar ve son derece savunmasız kallyorlar." diyerek bu önemi vurgulamaktadır (Robb, 2004).

Son y1llarda şehirlerin; yollar, köprüler, tüneller, hafif raylı sistemler, metrolar, havaalanları, limanlar, enerji, haberleşme ve bilgi sistemleri, su ve kanalizasyon sistemleri dâhil 


\section{M.Cem OĞULTÜRK' Güngör ŞAHINN}

Eleştirel Jeopolitik Çerçevesinde Akıllı Şehirler ve Şehir Jeopolitiği

tüm kritik altyapı tesislerini izleyen ve optimize eden, bakım ve güvenliğini sağlayan akıllı otonom sistemler olarak insan yaşamının bir parçası haline geldiği görülmektedir. Bu bakımdan akıllanan şehirlerin yapay zekâ ve robotik ile jeopolitik çalışmalarının ortak noktasında şehir jeopolitiği yaklaşımı yatmaktadır (Graham, 2004).

Şehir jeopolitiği pek çok sektörü içine alan ve oldukça kapsamlı bir süreçtir. $\mathrm{Bu}$ çalışmada; Şehirlerdeki güvenlik risk ve tehditleri nelerdir? Şehirlerde güvenlik risk ve tehditlerinin kaynağı ve sebepleri nelerdir? Şehirlerdeki güvenlik risk ve tehditleri karşısında hangi seviyede ve hangi aktörlerin iş birliği gerekmektedir? Şehir jeopolitiği nedir? sorularına cevap aranacaktır. Bu çalışmanın kuramsal çerçevesini; mevcut kuvvet-zaman-mekân ilişkisi bağlamında gelişen jeopolitik yaklaşım karşısında yeni ortaya çıkan güvenlik sorunlarıyla mücadelede alternatifler ve stratejik yaklaşımlar getiren eleştirel jeopolitik oluşturmaktadır. Çalışmada mevcut literatür kapsamında; yeni bir kavram olan şehir jeopolitiği, eleştirel jeopolitik kuramı, bugün ve yarına 1şık tutacak bir tarihsel çerçevede, teori ve pratik arasındaki sebep sonuç ilişkisini ortaya çıkarmak için nitel araştırma yöntemlerinden içerik analizi kullanılmıştır. Çalışmanın bulguları; şehir jeopolitiğinin, şehirde güvenliğinin korunmasında ve sağlanması ile şehrin her bakımdan yaşanabilir olmasında ilgili aktörleri ve sorumluluk alanlarını net bir şekilde tanımlamak ve bu aktörler arasında iş birliği bilincini geliştirecek ortak dil yaratmak maksadıyla bir araç olarak kullandığ şeklindedir.

\section{Teorik Çerçeve}

Ülkelerin coğrafyaları ile stratejik davranışları birbirleri ile yakından ilişkilidir. İbn-i Haldun'un da vurguladığı gibi çoğu zaman coğrafya, ülkelerin ve medeniyetlerin kaderini etkilemiştir (İbn Haldun, 2007). Nicholas J. Spykman'ın kısa tanımına göre jeopolitik; ülkelerin güvenlik politikalarının coğrafi faktörlere ve hadiselere göre planlanmasıdır (aktaran Wilkinson, 1985). Tanımdan da anlaşılacağı gibi jeopolitik ile güvenlik birbirinden ayrılmayan iki kavram olarak karşımıza çıkmaktadır. Soğuk Savaş sonrası ortaya çıkan yeni durum güvenlik algılamasını değiştirmiş, askeri tehdidin yanına insan hakları, enerjinin kaynaklarının paylaşımı, çevre güvenliği, kültürel değerler, küresel ve sosyal adaletsizlikler gibi konular eklenmiştir.

Güvenlik kavramındaki genişleme, jeopolitiği milli güvenlik kavramıyla irtibatlandırmış ve jeopolitiğe yeni bir işlev kazandırmıştır. Soğuk Savaş sonrası dönemde jeopolitik, mutlak konum, büyüklük, şekil (ada, yarımada, kıta içi vb.) gibi coğrafi özellik tanımlamaların ötesinde yeni bir anlama kavuşmuştur. Soğuk Savaş sonrası jeopolitik algının değişmesiyle birlikte "eleştirel jeopolitik" olarak adlandırılan analizler kapsamında, jeopolitik yeni bir bakış açısı kazanmıştır. Eleştirel kuram yeni bir bakış açısı ile uluslararası ilişkiler disiplinine yaklaşımı, jeopolitik alanın gelişmesini sağlamıştır. Cox temel olarak bir kuramın iki amacı bulunduğunu iddia etmiştir. Birinci amaç; mevcut düzeninin devamını sağlamak ve taktik uygulamaları açıklamaktır. Cox 
(1981), bu yaklaşımı "problem çözücü kuram” olarak tanımlamıştır. İkinci amaç ise; alternatif/yeni bir düzen kurgulamak ve stratejik uygulamalara rehberlik etmektir. İşte bu yaklaşım ise "eleştirel kuram" olarak tanımlanmaktadır. Problem çözücü kuram, dünyayı güç ilişkileri, sosyal ilişkiler ve bunların düzenlediği mevcut kurumlar çerçevesinde ele almaktadır. Uluslararası ilişkilerin eleştirel kuramları ile yakın ilişki içinde olan eleştirel jeopolitik, yaşadığımız dünyayı müphem ve anlaşılması zor kabul ederek uluslararası politika kuramlarını geliştirmeye çalışmaktadır (Dodds, 2005).

Bu kapsamda Agnew (2003), "eleştirel jeopolitiğin, uluslararası politika için coğrafi varsayımları ve tespitleri incelediğini” iddia etmektedir. Gearóid Ó Tuathail (2000), klasik jeopolitiği Batılı devletlerin emperyalist hedeflerini gerçekleştirmenin bir aracı olarak söylem yoluyla oluşturulduğu ve objektif olmadığı için eleştirmektedir (aktaran Atmaca, 2011). Bu çerçevede, jeopolitiğin söylem olarak hem siyasi ve sosyal hem de güç ve bilgi arasındaki ilişkilerle oluştuğu eleştirel jeopolitik düşünürlerince savunulmaktadır.

Klasik jeopolitik anlayışta; jeopolitik ile sadece devlet adamları, dış işleri mensupları ve kısmen akademisyenler ilgilenirken; eleştirel jeopolitikle birlikte siyaset yapıcılardan akademisyenlere, sivil toplum kuruluşlarından bireylere kadar geniş bir kitle bu konu ile yakından ilgilenmeye, çalışmalar yapmaya başlamıştır. Bu bakımdan, jeopolitiğin özneleri genişlemiş ve geniş bir kitle bu özneler grubuna dâhil olmuştur.

11 Eylül saldırısının yarattı̆ğ büyük ölçekli tahribat, “İşgal Et Hareketi”nin (Occupy Movement) yarattığı sonuçlar, radikal örgütlerin kentlerde yarattığı terör, modern kentsel alanların insan kaynaklı felaketlerin etkilerine ne denli açık ve savunmasız olduğunu ortaya çıkarmıştır. Dolayısıyla ulus-devletler, uluslararası terör ağları vb. insan kaynaklı tehditlerin üstesinden gelmek, yaşamsal önem taşıyan kritik altyapıyı doğal ve insan kaynaklı tehditlerden korumak için eleştirel jeopolitiğin geliştirilmesinde son zamanlarda kaydedilen ilerlemeye acil ihtiyaç duymaktadır. Eleştirel jeopolitiğin ulus altı hale gelmesi, stratejik şehirlerin jeopolitik alanlar olarak giderek artan rollerinin etkili bir şekilde analizinin yolunu açmıştır (Graham, 2004).

Şehir jeopolitiği çalışmaları, şehir ve savaş arasındaki ilişkiyi eşzamanlı olarak yeni, Soğuk Savaş sonrası bir ilişki ve bir modernite olarak tasvir etmektedir. Eleştirmenler ayrıca, 1989 öncesi ve sonrası yerel çatışmalar arasındaki bağlamsal sürekliliği vurgulayarak 'yeni savaşların' varsayılan yeniliğini incelemenin; yeni jeopolitik kodların ortaya çıkarmanın ve yeni jeopolitik gerçekler yaratmanın yöntemi olarak sunmaktadır (Fregonese, 2012). Soğuk Savaş sonrası artan etnik-dini iç çatışmalar ve şehirlerde çatışan devlet dış1 aktörlerin yoğunlaşması 1şığında, şehirlerdeki çatışmaların daha da artacağı ve şehirlerin küresel aktörlerin çıkarları doğrultusunda gelişen çatışmaların merkezleri olacağı söylenebilir (Fregonese, 2012). 


\section{M.Cem OĞULTÜRK' Güngör ŞAHIN}

Eleştirel Jeopolitik Çerçevesinde Akıllı Şehirler ve Şehir Jeopolitiği

Jeopolitiğin kavramsal yapısında yaşanan bu tür değişimler ve evrim, bu bilimin metodolojik bakışını ve hatta güç-politika ilişkilerinin geleneksel analizinden güç-şiddet ilişkilerinin analizine daha modern betimleme yaklaşımlarına kadar temel çerçeve sunmak amacıyla modern hermeneutik yaklaşımlara zemin hazırlamıştır (Ingram ve Dodds, 2016). Jeopolitiğin dinamik doğası, güç ilişkilerini ve güç bağlantılarını analiz etme becerisi, şehir içi ve şehirlerarası rekabetin gelişmesi, batı akademik sisteminde "kentsel-jeopolitik" olarak adlandırılan yeni bir disiplinin temelini oluşturmuştur. Yeni ortaya konulan ve az bilinen bir paradigma olarak "şehir jeopolitiği”" akademik yazında hermeneutik yaklaşımlardan birisi olarak karşımıza çıkmaktadır.

Kentsel jeopolitik üzerine az ama büyüyen bir literatür mevcuttur ve yapılan çalışmalar öncelikle kentsel alanlardaki çatışma ve terörle ilgilidir (Picket, 2019). Stephan Graham, şehir jeopolitiği kavramını jeopolitik ve politik yazın içerisinde ilk defa ortaya koyan ve kullanan olmuştur. Graham, 2004 yılında yayınlanan "Cities, War And Terrorism: Towards an Urban Geopolitics" adlı kitabında jeopolitik çalışmaların merkezinde şehirleri ve mahallelerini ele almakta, savaş ve terörün şehir hayat ile kesişimini farklı açılardan değerlendirmiştir. Şehir jeopolitiği kavramının Graham tarafından geliştirilmesinin ardından aynı yıl, ilk şehir jeopolitiği konferansı Fransa'da gerçekleştirilmiştir. Fransa şehir jeopolitiği çalışmalarının bir nevi merkezi olarak düşünülebilir. Bunda Fransa şehirlerinin özellikle Paris banliyölerinin heterojen kültür ve nüfus yapıs1; Afrika, Asya ve Doğu Avrupalı göçmenlerden oluşması ve neticesinde güç devşirmeye çalışan gruplar arası rekabete, şiddete, çatışmaya ve protestolara zemin hazırlamasının etkisi bulunmaktadır. 2005 yılında yaşanan olaylar Sarkozy yönetiminin kent jeopolitiğine yönelik çalışmalara yöneltmiş ve bu kapsamda ilk uluslararası konferans toplanmış ve ardından bu yeni perspektif çerçevesinde konuya akademik ilgi artış göstermiştir (Siami ve Abadi, 2008).

"Şehir güvenliği ve genel güvenlik" teması, farklı konuları ve bunlardan kaynaklanan endişeleri kapsamaktadır. Genel olarak, iaşe, ibate ve sağlık gibi temel ihtiyaçlardan; deprem ve sel gibi doğal afetler, şehirde savaş, terörizm veya saldırıdan korunma gibi toplu güvenlik ihtiyaçlarına kadar uzanır. Bununla birlikte, bu kaygı ve sorunlardan yalnızca birkaçı, uygun kentsel politika, planlama, tasarım ve yönetişim yoluyla insan yerleşimleri perspektifinden ele alınabilir. Kentsel Güvenliği ve Güvenliğin Arttırılması: İnsan Yerleşimleri Küresel Raporu 2007, şehirlerin güvenliği ve güvenliğine yönelik üç ana tehdide odaklanmaktadır: suç ve şiddet, iş güvenliği ve zorla işten çıkarma, doğal ve insan yapımı felaketler. Şehir sakinlerinin emniyet ve güvenliğine yönelik bu üç tehdit birleştiğinde, şu anda hem şehir hem de ulusal hükümetler ve uluslararası toplum için büyük bir zorluk oluşturmaktadır (United Nations Human Settlements Programme/UN-Habitat, 2007). 
Şehir jeopolitiği tanımlanırken klasik jeopolitik aktörlerin konumlarını korudukları ancak kurumsal ve ekonomik açıdan stratejik önemlerini artıran küresel şehirlerin yükselen bir şehir jeopolitiği aktörü haline geldikleri vurgulanmaktadır (Sassen, 2012). Şehir jeopolitiği, genellikle şehirlerin büyük jeopolitik anlatılar, özellikle de çatışma ve savaşla ilgili olanlar üzerindeki etkileri açısından çerçevelendirilmektedir (Picket, 2019). Rokem ve Boano (2018), şehir jeopolitiğinin kapsamını çatışma odaklı olmanın ötesine genişletmeye çalışmışlar ve şehir jeopolitiğini farklı boyutlarda ve temalarda incelemişlerdir. Pandemi döneminde şehirlerin sorunlarının arttığı ve çeşitlendiği görülmektedir. Bu durumun şehirlerin jeopolitik aktör haline gelmelerinin önünü açan bir sonuç yaratması olası görülmektedir.

\section{Şehir Güvenliği ve Şehir Jeopolitiği}

Savaş, terörizm, örgütsel suçlar ve şehirlerarasındaki kesişimin araştırılma ihtiyacı; küresel metropollerin jeopolitik çatışmanın kilit stratejik alanları haline gelmesi; düzenli ve düzensiz bir savaş stratejisi olan meskûn mahal muharebesi ve ideolojik şiddet olaylarına karşı düzenli ve düzensiz mücadele stratejisi gereksinimi; özellikle terörizmle mücadele kapsamında şehir jeopolitiği yaklaşımının 2000'li yılların başından itibaren giderek artmasının esas nedenleri olmuştur.

Şehir jeopolitiği, jeopolitiğin iki temel özelliğini açıklama peşindedir: Bir yanda jeopolitik belirli bir zümre, ölçek veya yapıyla sınırlı tutulamayan genel bir konudur. Bunun dışında, şehirler arası rekabet küresel çapta ülkeler arasında, ülke içinde ise hem şehirler hem de semtler arasında yaygındır. Diğer yandan, şehir jeopolitiği bir şehir içindeki ilçeler, sokaklar ya da şehrin farklı bölgeleri arasındaki rekabeti analiz edebilir ve ortaya çıkarabilir. Şehir jeopolitiği bu bakımdan, siyasal bilimler, uluslararası ilişkiler, sosyoloji, coğrafya, şehir planlama, mimari, tarih, strateji, güvenlik ve askeri bilimlerin bir bileşimi olarak tanımlanabilir.

Dünyanın dört bir yanındaki milyarlarca insan, şehirdeki temel hizmetlere ve haklara erişememekte, bu durum son birkaç on y1lda göreli ve mutlak bir büyüme göstermiştir. Uluslararası kurumlar, ulus devletler ve yerel yönetimler; şehirlerin finansman ve üretim mekanizmalarını bu gerçeği değiştirmek adına dönüştüremediler. Bunun sonucunda, dünya çapında yeni gerilimler ve güç ilişkileri ortaya çıkmıştır. Muhtemelen yeni sosyal aktörler, şehirlerin jeopolitiğinin yenilenmesi ile yeni bir diplomasi, yeni şehirleşme tarzı ile çevre kullanım ve koruma modellerini tetikleyebilir (Balbim, 2016).

Şehirler, siyasi, ekonomik, mali, sosyal ve toplumsal yaşamın merkezleridir. Bu sebeple şehirler, cazibe merkezi yaşam mekânları haline gelmektedirler. Bunlarla birlikte sosyal, ekonomik ve siyasal alandaki yetersizlikler, şehirlerde suç ve mağduriyet sorununu oluşturmaktadır. Ortaya çıkan bu sorunlar sonucunda, bireylerin yaşam alanlarına yönelik güvenlik algıları derinden etkilenmektedir. Bunun yanında yaygın suç ve şiddet, vatandaşlar 


\section{M.Cem OĞULTÜRK' Güngör ŞAHINN}

Eleştirel Jeopolitik Çerçevesinde Akıllı Şehirler ve Şehir Jeopolitiği

arasında korku, mağdurlarda da sarsıntı yaratmakla birlikte faillerin de toplum dışına itilmelerine, yakalanmaları durumunda ise ailelerinin de zarar görmesine ve dolayısıyla tüm toplumun etkilenmesine neden olabilmektedir.

İnsan hayatı, doğası gereği savunmasızdır ve bireysel, hane halkı, topluluk, mahalle, şehir ve ulusal düzeylerde şehir güvenliğini tehdit edebilecek çok çeşitli risklere veya tehlikelere açıktır. İnsanların savunmasızlığının kaynakları çok sayıda olsa da, temelde üç geniş kategoriye ayrilabilirler (United Nations Human Settlements Programme/UN-Habitat, 2007):

- İlk kategori, gıda, su, barınma ve sağlık gibi biyolojik ihtiyaçlarla ilişkilidir. İnsanların hayatta kalabilmeleri için bu ihtiyaçları asgari düzeyde karşılamaları gerekir. Bu ihtiyaçların karşılanmasındaki önemli aksaklıklar, sağlığın bozulmasına ve ölüme neden olabilir. Çoğu durumda, bu güvenlik açıkları kalıcıdır ve uzun vadeli niteliktedir.

- İkinci kategori bağlamsal güvenlik açıklarını içerir. Bir bireyin hayatını çevreleyen ve insanlar arasındaki etkileşimlerin yoğunluğu da dâhil olmak üzere insan yaşamının sosyal, ekonomik, politik ve çevresel bağlamlarından kaynaklanır. Bunlar, etnik şiddetin neden olduğu zararlar, ekonomik problemler nedeniyle gelir kaybını ve işsizlik, uyuşturucu kaynaklı suçlar veya hükümetin gecekondu mahallelerini kaldırmaya yönelik politikaları şeklinde sayılabilir.

- Üçüncü bir kategori, kasırgalar, depremler veya savaşlar dâhil olmak üzere doğal veya insan kaynaklı afetler gibi büyük, olağandışı, ancak dönemsel olaylardan kaynaklanan konuları içerir. Bu gibi şehir güvenliği ve genel güvenliğe yönelik tehditler farklı coğrafi analiz düzeylerindeki birçok faktörle; küresel, ulusal, kentsel, mahalle veya topluluk, ev halkı ve birey ile yakından bağlantılıdır. Bu yüzden de kapsamlı bir mücadele yöntemi içermelidir.

Özellikle büyük şehirlerde başta trafik, yoğun kalabalık, aşırı yapılaşma ve yeşil alanların azalması, bireylerin yaşam kalitesini olumsuz yönde etkilemektedir Diğer yönüyle yaşanılan şehrin daha iyi olması, yaşam kalitesinin yükseltilmesi, güçlü bir toplumsal ve kentsel kimliğin oluşturulması, insanların birbirleriyle etkileşim içinde olması hem toplumsal bütünleşme hem de toplumsal denetim açısından önemlidir. İnsanlar bulundukları şehre entegre oldukça hem yaşam kaliteleri hem de kentin nitelikleri artacaktır.

İnsanların yaşadıkları şehir ile aralarında bir bağ oluşturabilmelerinin yolu şehir planlamasından geçmektedir. Son yıllarda nüfusu yılda ortalama yüzde 1.23 artan ABD ve 1990 'dan 2003'e kadar nüfusu y1lda yalnızca yüzde 0,31 artan AB, mevcut ekonomik büyümeleri ile demografik büyümeleri arasında denge kurabilmektedir. Fakat dünyanın birçok bölgesindeki hızlı nüfus artışı şehir planlamasını hem siyasi hem de ekonomik olarak zorlaştırmaktadır (Dierwechter, 2008).

Güvenlik kavramı çok yönlü olduğu için, bir şehrin güvenlik meselesi, ulaşım, çevre ve toplumsal davranışlar bağlamında da ele alınmalıdır. Bu bağlamda şehrin güvenliğinin 
sağlanmasında da polis, şehir güvenliğinden sorumlu tek aktör olarak tanımlanmamalıdır. Günümüz mevcut güvenlik politikalarına değinildiğinde, sorumluların yalnızca güvenlik güçleri olarak görülmesinden dolayı, sadece önleyicilik ve caydırıcılık üzerine kurulmuş politikalar karşımıza çıkmaktadır. Polis dışındaki kurumların, güvenliği sağlama ve sorumluluğu paylaşma konusunda bilgi düzeyleri yetersizdir. Şehir güvenliğine yapılan çalışmaların eksik bir yönünü bu yetersizlik oluşturmaktadır. Dolayısıyla şehrin güvenliğinin sağlayabilmesi için tüm aktörlerin birlikte rol alacağı daha kapsamlı makro politikalara gereksinim vardır. Güvenlik kavramı, içinde birçok başlığı barındırmaktadır. Suç ve mağduriyet bu başlıklardan sadece birini oluşturmaktadır. Güvenlik tehditleri süreç içerisinde siyasi, sosyal, ekonomik, kültürel ve demografik yap1 içerisinde oluşmaktadır. Çok boyutlu güvenlik stratejileri gerektiren proaktif güvenlik anlayışı; eğitim, sosyal hizmetler, yerel ve merkezi yönetimler, sivil toplum, akademi ve iş dünyası gibi pek çok alanı kapsayan bütüncül planlamalardan meydana gelmektedir. Ayrıca göç, kentsel tasarım, kentsel dönüşüm ve konut politikaları ile de kent güvenliği arasında yakın bir ilişki bulunmaktadır.

Bir bütünün parçaları olmalarına rağmen, şehir merkezleri ile şehrin yakın çevresini oluşturan banliyöler arasında paylaşılan istihdamda yaşanan sorunlar, banliyölerde daha sert hissedilmektedir. Bir yönüyle de uluslararası ilişkilerdeki merkez-çevre ekonomik ilişkisi şeklinde bir durumun oluşmaması için hem yapısal hem de kentsel dönüşüm tedbirleri alınmalıdır. Bu nedenle şehir planlaması, bir tür şehir jeopolitiği olarak yorumlanabilir; burada mekânın (veya bölgenin) politik kontrolü, devletin genel sosyal projesinin merkezi bir parçasıdır. Geleneksel olarak anlaşılan şehir planlama, elbette "geçmişi, bugünü ve geleceği aynı kültüre bağlayan" kolektif bir plan geliştirme girişimidir. Şehir planlaması; karmaşık yeni problemleri çözmek için istenen bir dizi hedefe ulaşmak için kaynak ayırma ve seçilen stratejiyi uygulamak için gereken şekilde hareket etme gücü ve niyetinin katılımıla gelecekteki eylemin optimal bir stratejisini geliştirmeye yönelik kasıtlı sosyal veya örgütsel etkinliği içerir (Dierwechter, 2008).

21. yüzyılda savaş ve barış hali arasındaki çizgi silikleşmiş, savaşlar artık eskiden olduğu gibi ilân edilmemekte ve bir kere başladıktan sonra alışık olunmayan şablonlarda ilerlemektedir. İstikrar içindeki bir devlet, birkaç ay ve hatta gün içerisinde bir silahlı çatışmaya sahne olabilmekte, yabancı veya uluslararası bir gücün müdahalesine maruz kalabilmekte ve kaos, insani felâket, iç savaş bataklığına saplanabilmektedir. Geleceğin harekât ortamının getirdiği tehlike ve tehditlere karşı tedbirler almak, en başta bu ortamı tanımlamak ve anlamaktan geçmektedir. Bu faaliyetler arasında; siyasi ittifaklar, ekonomik tedbirler, propaganda, "dost" yabancı unsurların desteklenmesi, psikolojik harp ve hasım devletlerdeki muhalif unsurların teşviki gibi örtülü operasyonlar yer alabilmektedir. 


\section{M.Cem OĞULTÜRK' Güngör ŞAHIN}

Eleştirel Jeopolitik Çerçevesinde Akıllı Şehirler ve Şehir Jeopolitiği

Görünen o ki şehirler geleceğin harekât ortamının merkezinde yer almaktadır. Geçmişte şehirleri surlarla çevirmek ya da etrafına hendekler kazmak, içinde yaşayanlara tek başına güvenlik sağlayamamıştır. Çünkü şehir surları içerideki insanları dış düşmanlardan korumasına rağmen içerdeki baskı ve şiddetten koruyamamıştır. Son yirmi yıldır; kentlere, içlerinde yaşayanlara ve onlara işlerlik kazandıran destek sistemlerine karşı örgütlü, aşırı şiddet içeren eylemlerin çoğalması dünyamızın yeniden jeopolitik ve stratejik olarak şekillenmesine neden olmuştur.

Suriye krizi örneğinde yaşandığı şekliyle terör örgütlerinin meskûn mahal muharebesine ve şehirlerde terör eylemlerine yönelmesi, toplumsal olaylarda/hareketlerde yaşanan değişim ve küresel metropollerde/kentlerde (İstanbul, Londra, New York vb.) meydana gelen terör ve şiddet olayları, uluslararası göç, kent nüfusunda yaşanan artış, işsizliğin artışı, doğal afetlerin yarattığı zararlar, çevresel sorunların artışı, altyapı ve sağlık sorunları (salgın hastalıklar), yoksulluk, kişisel silahlanmanın artışı, teknolojinin yoğun kullanımı gibi pek çok sorun şehirlerin yönetilmesini giderek zorlaştırmaktadır.

Küresel eğilimler, suç oranlarının artmakta olduğunu göstermektedir. Örneğin, 19802000 döneminde, toplam kayıtlı suçlar her yüz bin kişi için 2300'den üç bine çıkmıştır. Bu eğilimin dünyanın tüm bölgelerinde aynı şekilde tekrarlanmadığı görülmektedir. Son yirmi yılda, Kuzey Amerika ve Batı Avrupa'da toplam suç oranlarında düşüşün yaşandığı, buna karşılık Latin Amerika ve Karayipler, Doğu Avrupa ve Afrika'da ise arttığı gözlemlenmektedir (United Nations Human Settlements Programme/UN-Habitat, 2007). Geleceğin şehirlerinin güvenliğini sağlamak için öncelikle şehirlerin karşı karşıya kalacağı risk ve tehdidin tanımlanması ve anlaşılması, sonrasında bu risk ve tehdide karşı strateji geliştirilmesi, son olarak uygulama için uygun eğitimli insan ile malzeme ve teçhizata sahip olmamız gerekmektedir. Geleceğin şehirlerinin güvenliği ancak bireyden devlet seviyesine kadar sivil, akademi ve kamunun ortak bir anlayış geliştirdiği kapsamlı yaklaşım çerçevesinde mümkün olabileceği değerlendirilmektedir.

Suç ve şiddeti azaltmak için tasarlanan politikalar birkaç geniş kategoriye ayrılır. Yerel düzeyde bunlar arasında etkili kentsel planlama, tasarım ve yönetişim; toplulukların çeşitli girişimleri sahiplendiği topluluk temelli yaklaşımlar; suçun faili ve mağduru olması muhtemel gruplara odaklanarak risk faktörlerinin azaltılması; bireylerin yeteneklerini geliştirmeye çalışan girişimler yoluyla sosyal yapının güçlendirilmesi bunlardan birkaçı olarak sayılabilir. Bu yaklaşımlardan tümü yerel düzeyde uygulamaya özellikle uygun olan, geniş bir strateji tarafından yönlendirilen ve yerel bağlamın dikkatli bir şekilde anlaşılmasına dayanan birkaçının birleşiminin başarı şansı yüksektir (United Nations Human Settlements Programme/UN-Habitat, 2007).

Şehirleri yok etme girişimlerini ya da şehirleri organize ideolojik şiddete yakından bağlayan 'karanlık' tarafını görmezden gelmek artık güvenlik ve şehir jeopolitiği alanında çalışan 
araştırmacılar için mümkün değildir. 11 Eylül ve terörizmle savaş sonrası dünyada şehir araştırmacıları, sosyal bilimciler ve uluslararası ilişkiler kuramcıları; kentsel ve alt ulusal alanları önemli jeopolitik alanlar olarak düşünmektedir (Graham, 2004).

Soğuk Savaş sonrası dönemin 'yeni' savaşlarında dünyanın gelişen şehirleri kilit yerler olarak öne çıkmakta, her şey gibi savaş da kentleşmektedir. Büyük jeopolitik çıkarlar, kültürel değişim, etnik çatışma ve sosyal karışım, ekonomik yeniden düzenleme ve serbestleşme; militarizm, kaynak sömürüsü, çevresel değişim artan ölçüde çağımızın kilit stratejik yerlerinde şiddetli çatışmalara dönüşmektedir. Dünyadaki jeopolitik mücadeleler, kentsel stratejik alanlar üzerindeki şiddetli çatışmalar etrafında gittikçe daha fazla eklemlenmekte ve birçok toplumda bu tür sivil savaşları çevreleyen şiddet, gündelik kentsel yaşamı güçlü bir şekilde etkilemektedir (Graham, 2011).

Teknolojideki gelişmeler ve küreselleşmenin sağladığı ortamın, tehditlerin tahrip edici etkisini artırması ve önleyici müdahale kavramının önem kazanması; sadece asker-polis-jandarma odaklı bir güvenlik yaklaşımının, yeni tehdit ve belirsizliklere karşı istenen nihaî başarı için yeterli olmaması; ortaya çıkan bir problemin tanımlanması ile bu problemin çözümü için üretilen plânın uygulanması arasındaki zaman farkı sebebiyle ortaya çıkacak tahribatın büyüklüğü; enerji, elektrik, su, iletişim, ulaşım vb. kritik alt yapı tesislerinin otomasyonu ile gün geçtikçe akıllı şehirlere dönüşen yaşam alanlarına güvenlik bağlamında jeopolitik bakış açısıyla bütünsel yaklaşılmasını zorunlu hale getirmektedir. Enerji, elektrik, su, iletişim, ulaşım vb. kritik alt yapı tesislerinde yaşanabilecek aksama ile eğitim, sağlık, barınma, iş, güvenlik gibi toplumsal sorunlar karşısında sadece yerel yönetimlerin çabalarının yeterli olmayacağı için şehir jeopolitiğinin bütünsel yaklaşımı ve akıllı şehir uygulamaları ülke içindeki tüm aktörlerin iş birliğini zorunlu kılmaktadır.

\section{Akıllı Şehirler ve Şehir Jeopolitiği}

1950'de dünya nüfusunun üçte ikisi kırsal ve üçte biri şehirliydi. 2050 yılına gelindiğinde, küresel demografik dağılımın bir asır öncesinin neredeyse tam tersi yani \%34 kırsal ve \%66 kentsel nüfus olacağ 1 tahmin edilmektedir. Tüm kentsel büyümenin yaklaşı \%90’1 Asya ve Afrika'da gerçekleşmekte ve yılda 70 milyon insan bu iki kıtanın bir yerindeki bir şehrin sakinleri olmaktadır. Araştırma tahminleri doğruysa, dünyanın kentsel nüfusunun 2050'de 6,3 milyara çıkacağı tahmin edilmektedir (Evans, 2016).

Şehirler, ulusal ekonomik faaliyetin, hükümetin, ticaretin ve ulaşımın çoğunun yoğunlaştı̆̆ı; kırsal alanlarla, şehirlerarasında ve uluslararası sınırların ötesinde önemli bağlantılar sağladıkları için hem kentsel hem de kırsal alanlarda kalkınmanın ve yoksulluğun azaltılmasının önemli itici güçleridir. Kentsel yaşam genellikle daha yüksek okuryazarlık ve eğitim seviyeleri, daha iyi sağlık, sosyal hizmetlere daha fazla erişim ve kültürel ve politik katılım 


\section{M.Cem OĞULTÜRK' Güngör ŞAHINN}

Eleştirel Jeopolitik Çerçevesinde Akıllı Şehirler ve Şehir Jeopolitiği

için gelişmiş fursatlar ile ilişkilendirilmektedir (UN Department of Economic and Social Affairs, 2014). Bu kapsamda şehirlerin güvenliği ve jeopolitiği, devletlerin ulusal refahının anahtarı olarak görülmelidir.

Şehir güvenliği meselesi aslında şehir jeopolitiğinin önemli bir yanı olmakla birlikte, şehrin refah ve yaşanabilirlik seviyesinin artırılması sonucunda jeopolitik öneminin ve çekiciliğinin artarak küresel şehir rekabeti içerisinde kendine yer edinmesi diğer yanını oluşturmaktadır. Son yıllarda bu konu hakkında yaşanan gelişmeler daha çok şehirlerin akıllanması çerçevesinde geliştiği görülmektedir. Her geçen gelişen iletişim teknolojileri ve yaşam biçimimizi değiştiren teknolojik devrim, bu devrimi hızlandıran uygulamalar bir bütün halinde akıllı şehir kavramı ile hayatımızın bir parçası haline gelmektedir. Küresel büyüme ve artan nüfusla birlikte terörizmden çevresel güvenliğe çok yönlü risk ve tehdit endişesi, teknolojik ve ekonomik sürdürülebilirlik adına yapılan yatırımlar ve dijital uygulamalar; akıllı şehir kimliği kazanmak için harcanan çabaları artırmıştır. Çin, Güney Kore ve Hindistan gibi ülkelerde tamamen yeni baştan inşa edilen ve dijital ağlarla altyapı kontrolü sağlanarak kaynakları etkin kullanmaya odaklı akıllı şehir tasarımları göze çarpmaktadır.

Mevcut literatür ve uygulamada, "akıllı kent" ya da "akıllı şehir" kavramı için farklı tanımlar ve yaklaşımlar kullanıldığı görülmektedir. Çevre ve Şehircilik Bakanlığ "Akk1lı Kent" kavramını "Paydaşlar arası iş birliği ile hayata geçirilen, yeni teknolojileri ve yenilikçi yaklaşımları kullanan, veri ve uzmanliğa dayalı olarak gerekçelendirilen ve gelecekteki problem ve ihtiyaçları öngörerek hayata değer katan çözümler üreten daha yaşanabilir ve sürdürülebilir şehirler" olarak tanımlamıştır (Çevre ve Şehircilik Bakanlığı, 2019). Ancak üzerinde uzlaşılan ortak bir tanım yapılamasa da bu ifadeden, şehirlerin sahip oldukları kaynaklarını etkin şekilde kullanma ve şehrin sakinlerinin daha iyi hizmet alabilmeleri için "modernleşme" çabası anlaşılmaktadır. Ayrıca, büyük şehirlerde artan hızlı nüfus ile birlikte sorunların katlanarak büyüdüğü görülmektedir. Bu sorunların artışı ile beraber ekonomik, toplumsal ve sosyal hayat olumsuz yönde etkilemekte, yaşam kalitesi azalmakta, şehirler marka ve rekabet gücünü kaybetmektedirler. Bu noktada akıllı şehir yaklaşımının, mevcut sorunlara akılcı çözümler üretebilme imkânı yaratabileceği düşüncesi ile devletlerin ve diğer uluslararası aktörlerin ajandasında yer almaktadır.

Amacının ise şehir altyapılarının ve şebekelerinin hiçbir insan müdahalesine ihtiyaç duymadan yapay zekâya ve nesnelerin internetine dayalı sistemlerle yönetilerek yaşam şartlarının önemli ölçüde iyileştirilmesi olduğu söylenebilir. Akıllı şehir yaklaşımına bu çerçeveden bakıldığında, yapılacak olan değişikliğin sadece bilgi ve iletişim teknolojilerinde yaşanan gelişmenin şehir ölçeğinde aktarılmasından ziyade vatandaşların yaşam kalitesinde fark yaratmayı amaçlayan bütünsel bir yaklaşım olarak görülmelidir. 
Bir şehri akıllandırma sürecinde en önemli konuların başında büyük veri analizi ve nesnelerin internetidir (Akdamar, 2017). Nesnelerin internetini, "birlikte çalışabilir otonom bilgi ve iletişim teknolojilerine dayanan fiziksel ve sanal şeyleri/nesneleri birbirine bağlayan, insan etkisine ihtiyaç duymadan gelişmiş seviyede hizmet üretebilen altyapı" (International Telecommunication Union) olarak tanımlamak mümkündür. Daha basit bir tanımla, "nesnelerin birbirleriyle haberleşmesini mümkün kılan iletişim altyapısı, nesnelerin interneti" (Terzi ve Ocakçı, 2017, s.12) olarak tanımlanabilir. Şehirlerde insanlara yönelik hizmetlerde yaşanabilecek sorunlar, çeşitli cihazlar, sensörler, iletişim ağ altyapıları, bulut sistemleri ve yazılımlar geliştirilerek çözüme kavuşturulması hedeflenmektedir. Bunu sağlamak için de teknolojik altyapının kurulması, verinin toplanması, verinin amaca yönelik işlenmesi ve sunulan hizmetlerin geliştirilmesi akıllı şehir sürecine yönelik en temel basamaklar olarak belirlenmiştir (Terzi ve Ocakç1, 2017, s.12).

Akıllı şehir kavramını oluşturduğu kabul edilen sekiz bileşeni; “Akıllı altyapı, akıllı güvenlik, akıllı enerji, akıllı yönetim, akıllı eğitim, akıllı sağlık hizmetleri, akıllı bina ve akıllı ulaşım/ hareketlilik" (Kayapınar, 2017, s.15) olarak sıralayabiliriz.

Mevcut eğilimler doğrultusunda dünyanın her bölgesinde kırsaldan şehirlere yönelen insan hareketliliği şehirlerde nüfus baskısı oluşturmaktadır. Bilimsel şehircilik planlama ve uygulamaları ile şehirleşmenin daha sağlıklı gelişmesi, düzensiz ve hızlı şehirleşmenin önlenmesi sağlanabilir. Buradan yola çıkarak akıllı şehirler, büyük metropollerin çevreci bir yaklaşımla ve teknolojinin kullanımı ile kontrol edilmesi (Kayapınar, 2017) olarak yorumlanabilir. Şehrin ihtiyaçlarının akıllı altyapı ve sosyal çevre ile sağlanması; çevre kalitesini önemseyen çevreye uyumlu akıllı tasarımların kullanılması; sağlık, eğitim ve ulaşım gibi kamu hizmetleri için bilgi teknolojileri kullanılması ve şehir güvenliğinde otonom sistemlerden faydalanılması akı1lı şehir uygulamalarına örnek olabilir. Akıllı şehirlere ülkemizde yaklaşım, ekonomik temelli sürdürülebilir gelişmeyi ve teknolojiyi esas alan, yaşanabilir şehirler yaratma hedefli olarak söylenebilir. Bu çerçevede, e-belediyecilik hizmetleri, sürücüsüz metro seferleri, turizm bilgi ve tanıtım sistemleri, elektronik denetim sistemleri, otoyol ve köprü geçiş sistemleri gibi uygulamalarla akıllı şehirlere erişmede önemli mesafe kaydedilmesi için, kamu kurum ve kuruluşlarından teknoloji konusunda çalışan özel şirketlere, belediyelerden vatandaşa toplumun tamamının göstereceği ortak çaba ile sağlıklı bir ilerleme sağlanabilir (Kayapınar, 2017).

Bu hususlara ilave olarak, şehirlerin karşı karşıya olduğu yeni öğreti; artık geniş bir ulus ötesi isyan yelpazesinin sosyal, teknik, politik, kültürel ve finansal ağlarda faaliyet gösterdiği fikrine odaklanmaktadır. Bunların, çağdaş şehirleri ayakta tutan altyapıyı ve kontrol teknolojilerini hedef alarak veya istismar ederek ölümcül tehditler oluşturduğu kabul edilmektedir. Bu tür gizlenmiş tehditlerin, geleneksel askeri veya emniyet güçlerine karşı 


\section{M.Cem OĞULTÜRK' Güngör ŞAHIN}

Eleştirel Jeopolitik Çerçevesinde Akıllı Şehirler ve Şehir Jeopolitiği

korunmak için şehirlerin karmaşası içinde kendilerini gizlediği varsayılmaktadır. Bu tehditlerle mücadele edebilmek için hem ulaşım ve altyapı sistemlerinin hem de günlük şehir yaşam alanları üzerinde odaklanan izleme ve güvenlik sistemlerinin akıllı şehir uygulamaları kapsamında geliştirilmesi gerekmektedir (Graham, 2011).

Aynı zamanda güvenlik güçleri, gelişmiş dünyadaki şehirlerde sivil itaatsizliği ve terörü önlemek için gerekli bir unsur olarak görülmektedir. Sivil olaylar (IMF, G8 veya Dünya Bankası zirveleri gibi) ve küreselleşme karşıtı hareketlerin kışkırttığı protestolar söz konusu olduğunda, devletler kentsel alanlar çevresinde çeşitli güvenlik kuvvetleri konuşlandırmaktadır. Polisin işlevleri ordununkilerle karıştığında, hareket ve toplanma hakları sınırlanmakta ve göstericileri dağıtmak için genellikle şiddet içeren yöntemler kullanılmaktadır. Buna ek olarak, göstericilerle teröristler arasındaki ayrım zaman zaman biraz bulanıklaşmakta, başlangıçta askeri kullanım için geliştirilen yeni teknolojilerin, sivillerin herhangi bir yerde, açıkça güvenliklerini garanti altına alma bahanesiyle davranışlarını ve hareketlerini izlemek ve kontrol etmek için nasıl kullanıldığ görülmektedir (Svitková, 2014).

Pandemi döneminde akıllı şehir uygulamalarının insanların günlük yaşantılarını kolaylaştırmanın yanı sıra insan güvenliği çerçevesinde takip uygulamalarının artışına da neden olduğu görülmektedir. Geçen sürede küresel şehirlerin merkezi hükümetten daha bağımsız hareket etme çabalarının merkezi hükümetleri rahatsız edecek boyutlara geldiği görülmektedir. Merkezi hükümetlerin küresel şehirlerin ihtiyaçlarını karşılamada yetersiz kalmaları küresel şehirlerin birer jeopolitik aktör haline gelmelerinin yolunu açmada ve şehir jeopolitiği çalışmalarına ivme kazandırması olası görülmektedir.

Şehir jeopolitiği kapsamında, belirli sorunlar karşısında istenilen etkiyi yaratmak için sadece askerî ve polisiye seçenekler değil siyasî, ekonomik, toplumsal güç unsurları ile bilgi ve teknoloji bir sistem yaklaşımı içerisinde kullanılmalıdır. Şehir jeopolitiğinin uygulama aracı olan akıllı şehirlerde; kritik sistemler ve bu sistemleri birbirine bağlayan düğüm noktaları vasıtasıyla teknoloji ve insan etkileşimi artırılarak tehdit ve sorunlar karşısında proaktif olunması sağlanabilir. $\mathrm{Bu}$ kapsamda toplumsal huzur, refah ve güvenliğin sağlanması için kanun uygulanması ve suç önleme, terörle mücadele, milli güvenlik ve savunma, bilgilerin yayılması dâhil acil durum yönetimi, iş güvenliği, koruyucu güvenlik (insan, mal vb.), e-güvenlik, doğal afet güvenliği, piyasa düzenlemesi, planlama ve altyapı geliştirme gibi birçok konunun eşgüdüm içeren yürütülmesi için günümüzde akıllı şehirlere daha çok ihtiyaç duyulmaktadır (Gordon ve Dion, 2008). 


\section{Sonuc}

Maslow'un (aktaran Mcloud, 2020) ihtiyaçlar hiyerarşisi piramidinin ikinci basamağını güvenlik ihtiyacı oluşturduğuna ve Arnold Wolfers'ın (1952, s.484-485) tanımı ile güvenlik sahip olunan değerlere yönelik bir tehdidin ve bundan kaynaklı korkunun olmaması olarak tarif edildiğine göre, merkezi ve yerel yönetimlerin en önemli görevlerinden birisi huzur ve güven sağlamak olarak belirlenebilir. Kopenhag Okulu tarafından geliştirilen sektörel güvenlik yaklaşımı ile askeri, siyasi, ekonomik, toplumsal ve çevresel konuların güvenlik alanına dâhil edilmesi ile artan şehir nüfusundan kaynaklanan sorunlar bir arada değerlendirildiğinde merkezi ve yerel yönetimlerin karşı karşıya kaldığı sorunlar artmıştır.

Yeni güvenlik ortamında savaş, çatışma, toplumsal olaylar ve terörizm şehirlere taşınmakta, ortaya çıkan tehditler hibrit olarak nitelendirilmektedir. Hibrit tehditler ile birleşen şehirlerin olağan sorunlarının çözümüne yönelik disiplinler arası bir bakış açısı gerekmektedir. Bu bakış açısı ise kuvvet-zaman-mekân arasındaki ilişki ile geleceğe yönelik öngörüde bulunan jeopolitik ve bu bakış açısını şehirlere uygulayan şehir jeopolitiği yaklaşımı ile sağlanabilir.

Güvenlik çerçevesinde bakıldığında, yirmi birinci yüzyılın kentsel alanlarında faaliyet gösterecek güvenlik güçlerinin başarısı, mega şehirler için etkili operasyonel yöntemler ile birlikte yeni kadro-malzeme-teşkilatları bünyesine adapte etmesine bağlıdır. Şehirlerde müdahale ve şiddeti azaltmayı amaçlayan angajman kuralları ve operasyonel çözümler geliştirmek, güvenlik ve emniyet güçlerini kentsel ağırlıklı bir dünyada gelecekteki çatışmaların zorluklarıyla yüzleşmek için daha hazırlıklı hale getirecektir. En kötü güvenlik ortamı olduğu düşünülen mega şehirler için öğrenilmiş stratejik bilgi, belirsizlik ve öngörülemezliktir.

2050 yılına kadar, kırsaldan ezici bir çoğunlukla kentsel alana yönelecek dünya nüfusu gerçeği, kentsel çatışmanın anatomisini anlamak için mevcut basit veya tekil bir şablonun olmaması ne şehir çalışmaları uzmanlarına ne de güvenlik uzmanlarına açık bir rehber sunmamaktadır. Daha fazla net bilgi elde etmek ve geleceğe doğru güvenle ilerlemenin en iyi yolu; üniversiteler, düşünce kuruluşları, kamu ve özel sektör çalışanları ile güvenlik birimleri arasında kurulan iş birlikleri yoluyla bütünsel analizlerin gerçekleşmesidir. Bahse konu şehir jeopolitiği yaklaşımı ile konuya bütünsel bir bakış açısı sağlanacağı, geleceğin şehirlerinin güvenli ve yaşanabilir bir modelinin oluşturulacağı, geleceğin akıllı ve güvenli kentlerine yönelik önemli adımlar atılabileceği değerlendirilmektedir.

Şehir jeopolitiği kapsamında küreselleşme, teknolojik gelişme, ulaşım ve iletişimin hızlanması, bilginin katlanma hızının artması sonucu ortaya çıkan yeni tehdit ve risklere karşı kapsamlı bir yaklaşım benimsenerek yeni programlar geliştirilmeli, kaynağı ne olursa olsun kritik altyapıya yönelik tehdit ve risklerin önlenmeli, çeşitli aktörler (kamu, özel, vb.) arasında koordinasyon sağlanmalı, eğitim-sağlık-iş güvenliği konularında toplumun beklentileri 


\section{M.Cem OĞULTÜRK' Güngör ŞAHİN}

Eleştirel Jeopolitik Çerçevesinde Akıllı Şehirler ve Şehir Jeopolitiği

karşılanmalıdır. Şehir jeopolitiği yaklaşımıyla bahse konu sorunların çözüme kavuşturularak toplumsal huzur, refah ve güvenliğinin sağlanması akıllı şehirler ve proaktif uygulamalarla mümkün olacaktır.

Türkiye'de akıllı şehir kavramına yönelik çalışmalar, araştırma ve yatırımlar şehir yaşantısının dayattığı bir zorunluluk olarak başlamış olsa da henüz çok ileri bir seviyeye ulaştığını söylemek mümkün değildir. Fakat Türkiye'de kent güvenliği üzerine tartışmalar yapılmakta, projeler hazırlanmakta, makaleler ve kitaplar yayınlanmaktadır. Eleştirel jeopolitik üzerine bir literatür oluşmakla birlikte; bütünsel olarak kent güvenliği, akıllı şehirler ve eleştirel jeopolitiğin iç içe geçtiği ve bir arada değerlendirildiğinde şehir jeopolitiği çerçevesinde çalışma yapılmadığı görülmektedir.

\section{Kaynaklar}

Agnew, J. (2003). Geopolitics- Re-visioning World Politics. Routledge.

Akdamar, E. (2017). Akıllı Kent İdealine Ulaşmada Büyük Verinin Rolü. Kent Kültürü ve Yönetimi Hakemli Elektronik Dergi, 10(2).

Atmaca, A.Ö. (2011) "Yeni Dünyada Eski Oyun: Eleştirel Perspektiften Türk-Amerikan İlişkileri”. Ortadoğu Etütleri, 3(1).

Balbim, R. (2016). Prolegomena: The Hope in The Cities. The Geopolitics of Cities: Old Challenges, New Issues, Institute for Applied Economic Research.

Cox, R.W., (1981). Social Forces, States and World Orders: Beyond International Relations. Millennium - Journal of International Studies, 10 (2), 126-155.

Çevre ve Şehircilik Bakanlığı. (2019). https://www.akillisehirler.gov.tr/akilli-sehir-nedir/ (Erişim tarihi: 29.10.2020).

Çevre ve Şehircilik Bakanlığı. (2017). Şehircilik Şurası Komisyon Raporları. Ankara.

Dierwechter, Y. (2008). Urban Growth Management and Its Discontents-Promises, Practices, and Geopolitics in U.S. City-Regions. New York: Palgrave Macmillan.

Dodds, K.J. (2005). Global Geopolitics, A Critical Introduction. Routledge.

Evans, M. (2016). Future war in cities: Urbanization's challenge to strategic studies in the 21st century. International Review of the Red Cross. 98 (1), 37-51.

Fregonese, S. (2012). Urban Geopolitics 8 Years on Hybrid Sovereignties, the Everyday, and Geographies of Peace. Geography Compass 6/5. Blackwell Publishing, 290-303.

Graham, S. (1998). Global Grids of Glass: On Global Cities, Telecommunications and Planetary Urban Networks. Urban Studies, 36.

Graham, S. (2004). Cities as Strategic Sites: Place Annihilation and Urban Geopolitics. Cities, War and Terrorism: Towards an Urban Geopolitics. Oxford: Blackwell Publishing.

Graham, S. (2010). When Infrastructures Fail. Disrupted Cities When Infrastructure Fails. New York: Routledge.

Graham, S. (2011). War Re-enters the City. Cities Under Siege: The New Military Urbanism. London: Verso. 
Ingram, A. ve Dodds, K. (2016). Spaces of Security and Insecurity: Geographies of the War on Terror. Routledge.

International Telecommunication Union, "Internet of Things Global Standards Initiative", https://tinyurl.com/y3sz9r6d (Erişim tarihi: 29.10.2020).

İbn Haldun (2007). Mukaddime. Çev. Süleyman Uludağ, İstanbul: Dergâh Yayınları.

Kayapınar Y.E. (2017). Akıllı Şehirler ve Uygulama Örnekleri. İTÜ Vakfi Dergisi. 77.

Küçükay, A. (2019). Suç Önleme Stratejileri ve Güvenlik Politikalarına Psikolojik Bir Bakış. Türkiye Adalet Akademisi Dergisi, 38.

Mcloud, S. (2020). Maslow's Hierarchy of Needs, https://www.simplypsychology.org/maslow.html (Erişim tarihi: 15.12.2020).

Gordon, K. ve Dion, M. (2008). Protection of 'Critical Infrastructure' and the Role of Investment Policies Relating to National Security”. Investment Division, Directorate for Financial and Enterprise Affairs Organisation for Economic Co-operation and Development. Paris.

Pickett, N. (2019). "Emergent Stateness: Critical Urban Geopolitics in Slavutych. East/West". Journal of Ukrainian Studies. 6 (11-31).

Robb, J. (2004). Cascading System Failure, https://globalguerrillas.typepad.com/ globalguerrillas/ 2004/ 05/cascading_syste.html (Erişim tarihi: 15.12.2020).

Rokem, J. ve Boano, C. (2018) Urban Geopolitics: Rethinking Planning in Contested Cities, Routledge, New York.

Sassen, S. (2012). An Emergent Urban Geopolitics, http://www.saskiasassen.com/pdfs/london/an-emergent-urban-geopolitics.pdf (Erişim tarihi: 15.12 .2020 )

Siami, Q. ve Abadi, H.K. (2008). Urban Geopolitics and Violence to Iranian cites, Critical theory of urban destruction in Iraq war with Iran", https://scholar.google.com.tr/scholar?q=Urban+Geopolitics+and+Violence+to+Iranian + cites\&hl=tr\&as_sdt=0\&as_vis=1\&oi=scholart (Erişim tarihi: 29.10 .2020$)$

Svitková, K. (2014). Contemporary Security from The Urban Standpoint: Cities in The Face of Risks and Strategic Threats for Spain. Journal of the Spanisch Institute of Strategic Studies. 3.

Terzi, F. ve Ocakçı, M. (2017). Kentlerin Geleceği: Akıllı Kentler. İÜ̈ Vakfi Dergisi, 77.

Tuathail, G.Ó. (2000). The Postmodern Geopolitical Condition: States, Statecraft, and Security at the Millennium. Annals of the Association of American Geographers. 90 (1).

Wilkinson, D. (1985). Spykman and Geopolitics. C.E. Zoppo and C. Zorgbibe (ed.), On Geopolitics: Classical and Nuclear. NATO ASI Series, Vol 20, Dordrecht: Springer.

Wolfers, A. (1952) National Security As An Ambiguous Symbol. Political Science Quarterly. 67 (4).

UN Department of Economic and Social Affairs. (2014). World Urbanization Prospects: The 2014 Revision - Highlights. New York.

United Nations Human Settlements Programme (UN-Habitat). (2007). Enhancing Urban Safety And Security Global Report On Human Settlements 2007. London: Earthscan. 